\title{
The National Tree Seed Centre Celebrates 40 Years
}

\author{
by J.D. Simpson ${ }^{1}$ and B.S.P. Wang ${ }^{2}$
}

\begin{abstract}
The National Tree Seed Centre has been providing seed of known origin and quality for research for 40 years. Seed is also stored for long-term gene conservation purposes to provide a source of germplasm for future research and restoration. This is particularly important for species facing such threats as insect attack, disease, climate change, or conversion of forest land to non-forest uses. The Centre's inventory focuses on native tree and shrub species, striving to store samples from throughout their ranges. Over 26000 seed samples have been sent to researchers in 65 countries, $70 \%$ of these samples being distributed within Canada. Seed research has always been a component of the Seed Centre's program. One notable accomplishment is the development of the Petawawa Germination Box. The Seed Centre participates in and contributes to activities of the Association of Official Seed Analysts, the International Seed Testing Association, and the IUFRO Seed Physiology and Technology Research Group.
\end{abstract}

Key words: collection, dormancy, ex situ gene conservation, germination, research, seed, storage

\section{RÉSUMÉ}

Le Centre national de semences forestières fournit au secteur de la recherche des semences d'origine connue et de qualité depuis 40 ans. Les semences sont également entreposées à long terme à des fins de préservation génétique dans le but de constituer une source d'embryons pour la recherche future et le reboisement. Ceci est particulièrement important dans le cas des espèces faisant face à des menaces comme des épidémies d'insectes, des maladies ou la conversion des terres autrement que pour des utilisations forestières. L'inventaire du Centre porte principalement sur les espèces arboricoles et arbustives indigènes, veillant à conserver des échantillons pour l'ensemble de leur aire de dispersion. Plus de 26000 échantillons de semences ont été expédiés à des chercheurs de 65 pays, 70 \% de ces échantillons étant destinés au Canada. La recherche sur les semences a toujours fait partie du programme du Centre de semences. La mise au point du Contenant de germination Petawawa constitue un exemple tangible des travaux effectués. Le Centre de germination participe et contribue aux activités de l'Association of Official Seed Analysts, de l'International Seed Testing Association et du Groupe technique de recherche de l'IUFRO sur la physiologie des semences.

Mots clés : collection, dormance, préservation génétique ex situ, germination, recherche, semences, entreposage

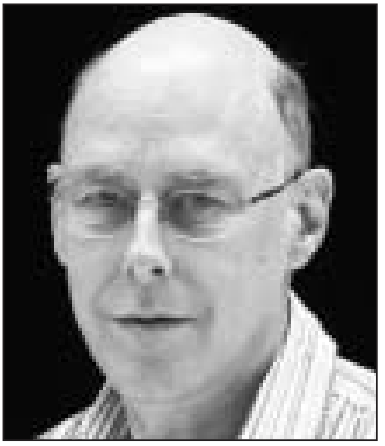

J.D. Simpson

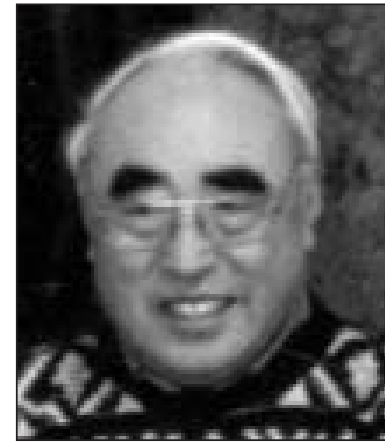

B.S.P. Wang

\section{Introduction}

Tree seed is essential for reforestation and is often an important component for forest research. Obtaining good quality seed from a variety of species and locations can be a challenge. Canadian provinces maintain seed storage facilities to store large quantities of seed that is used to supply reforestation programs for commercially important species; several of the provincial centres store smaller quantities of seed from non-commercial species. However, in the 1960s, the Canadian Forest Service (CFS) recognized the need to establish a seed centre to collect and obtain seed, and provide it for research purposes to researchers within the CFS as well as to other national and international agencies. At the same time, reforestation programs were expanding in Canada and there was a need for research and technology transfer concerning seed collection, testing, and storage. The National Tree Seed Centre was established in 1967 with the basic purpose to provide seed of known origin and quality for research. The Seed Centre has experienced significant change over the past 40 years, but is still sought out to provide seed for research. This article gives a brief history of the Seed Centre, and discusses its current status and role, its impact on seed science nationally and internationally, and its future role.

\section{The First 30 Years}

In the 1960s, tree genetics and breeding research was burgeoning across Canada. Demand was high for small quantities of seed of known origin and quality for provenance testing. In response to this need, the Canadian Forest Service

\footnotetext{
1 Natural Resources Canada, Canadian Forest Service - Atlantic Forestry Centre, National Tree Seed Centre, P.O. Box 4000, Fredericton, New Brunswick E3B 5P7. E-mail: dsimpson@nrcan-rncan.gc.ca

${ }^{2}$ Natural Resources Canada, Canadian Forest Service - Great Lakes Forestry Centre, Petawawa Research Forest, P.O. Box 2000, Chalk River, Ontario K0J 1J0.
} 


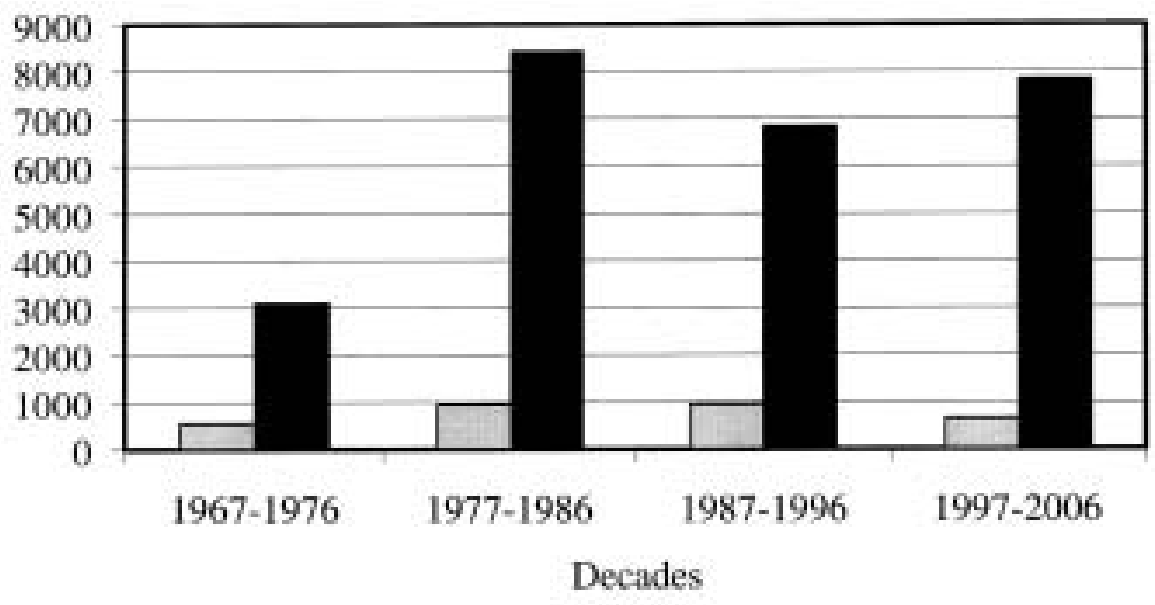

No. requests $\mathbf{D}$ No. seedlots

Fig. 1. Number of requests for seed and number of seed samples provided by the National Tree Seed Centre within each of four decades.

established the National Tree Seed Centre in Chalk River, Ontario at the former Petawawa Forest Experiment Station. The Seed Centre was created at a time when reforestation programs were expanding in Canada: there was a requirement for large quantities of seed and a concomitant need for appropriate collection, processing, testing, and storage methods. Germination testing protocols existed for the major conifer reforestation species, but in some cases, fine tuning was required. As well, there was a need to investigate various factors impacting germination, such as seed dormancy and such factors as changes in light, temperature, and moisture. A number of well-attended workshops on seed testing were held across Canada in the late 1980s to improve and standardize testing methods, and to improve standards and abilities for interpreting seed test results. A significant accomplishment of the Seed Centre was the development of the Petawawa Germination Box in response to the need for a container of appropriate size to permit maximum use of germinator space, allow full development of germinants, and maintain uniform moisture levels in the germination medium (Wang and Ackerman 1983). The germination box is widely used in Australia, Canada, New Zealand, and the United States, as well as in 15 countries in Africa, Asia, and Europe.

\section{The Next 10 Years}

In 1995, the Government of Canada conducted a government-wide program review to determine priorities. For the Canadian Forest Service, the end result was that research activities were organized into 10 national networks, and one laboratory and two institutes-including the Petawawa National Forestry Institute (PNFI) - were closed. Upon closure of PNFI, the Seed Centre was transferred to the CFS research centre in Fredericton, NB, where the Biodiversity Network was centered. Existing facilities at the Fredericton laboratory were modified to meet the requirements of the
Seed Centre. About 2500 glass jars containing 10000 seedlots were shipped from Petawawa in June 1996 and within two weeks of their arrival the seed jars had been organized in storage. Only one jar was broken during the move!

The Seed Centre's facilities include two $-20^{\circ} \mathrm{C}$ walk-in freezers with 285 lineal meters of shelving, one $4^{\circ} \mathrm{C}$ cooler with 35 lineal meters of shelving, seven germination cabinets, an x-ray machine, a cone-drying room, and laboratory space for processing and testing. A cryogenic facility was also established to permit storage of plant tissue for research and for long-term storage. The database, which includes information about each seedlot (e.g., provenance, geographic coordinates, germination, quantity, etc.), was transferred and set up on a PC running Microsoft Access. The original structure was maintained, but new queries, forms, and reports were developed. In 2006, the database was migrated to Oracle Database and now runs on a network server to enable the data to be accessed for CAFGRIS (Canadian Forest Genetic Resources Information System) (https://cfsnet.nfis.org/cafgris/index. html). This allows an investigator to view the geospatial distribution of seedlots for each species as well as to obtain pertinent information about each seedlot.

The transfer of the Seed Centre to New Brunswick provided an opportunity to evaluate the Centre's mandate. The original goal of the Centre, to provide seed for research purposes, was maintained. This continues to be an important role, with about 60 requests processed annually. Approximately $70 \%$ of the requests come from Canadian clients. Seed has been shipped to 65 countries over the past 40 years, with over 26000 seed samples provided for more than 3000 requests. Although the number of requests for seed declined during the last 10 years (1997-2006), the number of seed samples provided has remained at a similar level to that experienced during the previous 20 years (1977-1996) (Fig. 1). Seed has been requested for studies examining genetic diver- 
sity, germination and physiology, tissue culture, somatic embryogenesis, and mycology/pathology. Seed has also been supplied to arboreta and for species and provenance trials.

Seed performance and research results can be gauged through acknowledgment of the Seed Centre in publications. An example of the successful use of seed is the superior performance of Canadian tree species in China. Over a 20-year period, seed from many species was provided to the Liaoning Provincial Academy of Forest Sciences, Shenyang, Liaoning Province, where it was planted in trials with native species. Wang et al. (2006) reported that jack pine (Pinus banksiana Lamb.), pitch pine ( $P$. rigida Mill.), and eastern white pine $(P$. strobus $\mathrm{L}$.) were well adapted to the environment as demonstrated by normal seed production, excellent growth, and little damage by local pests.

It is important to continue to increase the number of accessions and species in storage. The Seed Centre is the national repository of germplasm from tree and shrub species. Therefore, a goal is to store material from throughout the Canadian range of native tree and shrub species. This is accomplished by staff making collections, purchasing seed, receiving donations, and collaborating on projects. Seed is either collected in bulk from many individual plants or from a single tree or shrub. Most researchers prefer to receive seed collected from an individual tree or shrub. Therefore, seed collection efforts by Seed Centre staff focus on individual collections from a minimum of 15 trees or shrubs in a population.

Long-term storage of seed is important for ex situ gene conservation. Some of the accessions date back to the 1950 s and 1960s when these collections were made for range-wide provenance tests for such species as jack pine, black spruce (Picea mariana [Mill.] BSP), and white spruce (P. glauca [Moench] Voss). With forest genetic resources threatened by climate change and invasive alien species, it is more important than ever to conserve samples of the gene pool that may prove useful for future restoration or research. Some examples of these species include: pitch pine, consisting of small populations at the northern fringe of its range, where climate change will favour northern expansion of its range; ash species, which are threatened by the emerald ash borer (Agrilus planipennis); and limber pine (P. flexilis James) and whitebark pine ( $P$. albicaulis Engelm.), which are threatened by white pine blister rust (Chronartium ribicola), climate change, and mountain pine beetle (Dendroctonus ponderosae).

\section{Impact of the National Tree Seed Centre}

Research is also an important component of the Seed Centre's program. Projects are designed to address operational and technical aspects of seed processing, testing, and storage. Because of the variety of tree and shrub species the Seed Centre stores, existing germination testing protocols must be regularly evaluated, and new protocols developed, especially when there is little or no published information. In fact, published or known testing procedures may not work consistently when dealing with seed collected from different locations because individual populations of trees may have adapted to respond to the particular environment in which they are growing. Examples include: sugar maple (Acer saccharum Marsh.) — seed from New Brunswick requires 12 weeks of moist chilling to alleviate dormancy, whereas seed from Ontario needs eight weeks; black ash (Fraxinus nigra Marsh.) _ published treatments for germination of seed from Manitoba, which recommend 126 days of warm stratification followed by 126 days of moist chilling (Vanstone and LaCroix 1975), do not work on New Brunswick sources, which require 60 days of cold, 120 days of warm, and 180 days of cold to maximize germination; white spruce, eastern white pine, and lodgepole pine (Pinus contorta Dougl.)—dormancy varies among trees within a stand, among stands, among provenances, and among seed crop years.

Moist chilling has many beneficial effects on seed germination and early seedling development. In addition to what is already known, new benefits that have been identified include: reducing the impact of improper seed handling; mitigating the impact of micro-environmental conditions that can occur in a germinator; triggering natural repair mechanisms; and increasing the rate of germination of non-dormant tree seeds (Wang 1987, Wang and Berjak 2000). Through cooperative testing, the treatment of white spruce seeds was changed in the Rules of the Association of Official Seed Analysts (AOSA) to allow for moist chilling of seed from northern sources. Laboratory germination criteria were developed for red pine (Pinus resinosa Ait.) and white spruce seed (Wang 1973, 1976).

Quality control criteria have been developed for seed collection and handling, timing of collection, and artificial ripening of white spruce and red pine cones (Winston and Haddon 1981). White spruce cones require post-harvest ripening, but the duration of the ripening period varies from year to year depending on heat sum accumulation during cone development (Caron et al. 1990, 1993).

The quantity of germination test data that has accumulated over 30 years of testing provides an opportunity to evaluate the storage life of tree seed. Data were evaluated for a number of species, and the results imply that seed can possibly be stored quite well for 100 years (Simpson et al. 2004). These same seedlots will be retested over time, and the seed storage potential will be re-evaluated.

In the late 1960s, the Seed Centre joined the Tree and Shrub Seed Subcommittee of AOSA, and became an accredited laboratory member of the International Seed Testing Association (ISTA) in 1973. Through this collaboration, research results were incorporated in the ISTA Tree and Shrub Seed Testing Handbook (Wang and Pitel 1991). In the 1980s, the Seed Centre provided facilities for training scientists and technicians from the CIDA ASEAN Forest Tree Seed Centre Project in Southeast Asia (Case and Wang 1990) and technical advice to the SADAC Tree Seed Centre Project in southern Africa (Wang 1988). The Seed Centre has been involved in IUFRO activities since 1973, actively participating in and contributing to symposia and conferences sponsored by the Research Group on Seed Physiology and Technology (e.g., Wang and Pitel 1982, Wang and Simpson 2004, Simpson and Daigle 2007, Wang 2007). 


\section{Future Outlook}

The National Tree Seed Centre will continue to provide seed for research because there continues to be a demand for this service. The Seed Centre is unique in that it stores tree and shrub seed from native Canadian species. The inventory will continue to grow as seed is acquired from new locations and from additional species by active collection and participation and collaboration in various projects and with various agencies. People involved in or starting a project that involves collecting seed are encouraged to contact the Seed Centre to explore ways and means for the Seed Centre to collaborate. In this way, germplasm collected for a particular project can be stored and possibly be used for other research.

On-going research will be carried out to develop and improve germination testing protocols, as well as to evaluate the long-term seed storage potential for many species, particularly those that have been identified as being of concern or where populations are threatened or a species is in decline in part of its natural range. Storing seed for long-term conservation purposes is a practical means of conserving the natural genetic variation found within a species so that it is available in the future for research or restoration planting.

\section{References}

Caron, G.E., B.S.P. Wang and H.O. Schooley. 1990. Effect of tree spacing, cone storage, and prechilling on germination of Picea glauca seed. The Forestry Chronicle 66: 388-392.

Caron, G.E., B.S.P. Wang and H.O. Schooley. 1993. Variation in Picea glauca seed germination associated with the year of cone collection. Canadian Journal of Forest Research 23: 1306-1313.

Case, A.B. and B.S.P. Wang. 1990. Helping reforestation in Southeast Asia - the ASEAN-Canada Forest Tree Seed Centre Project. The Forestry Chronicle 66: 246-249.

Simpson, J.D. and B.I. Daigle. 2007. Five years' storage of seed from three Salix species. In T.L. Beardmore and J.D. Simpson (eds.). Proceedings, Recent Advances in Seed Physiology and Technology, IUFRO Research Group 2.09.00, 18-21 July 2006, Fredericton, NB, Canada. pp. 30-38.

Simpson, J.D., B.S.P. Wang and B.I. Daigle. 2004. Long-term seed storage of various Canadian hardwoods and conifers. Seed Science and Technology 32: 561-572.

Vanstone, D.E. and L.J. LaCroix. 1975. Embryo immaturity and dormancy in black ash. Journal of the American Society of Horticultural Science 100: 630-632.
Wang, B.S.P. 1973. Laboratory germination criteria for red pine (Pinus resinosa Ait.) seed. Proceedings of the Association of Official Seed Analysts 63: 94-101.

Wang, B.S.P. 1976. Dormancy and laboratory germination criteria of white spruce seed. In Proceedings of the $2^{\text {nd }}$ IUFRO International Symposium on Physiology of Seed Germination, Fuji, Japan. pp. 179-187.

Wang, B.S.P. 1987. The beneficial effects of stratification on tree seed germination. In Proceedings of the Ontario Nurserymen's Meeting, 15-19 June 1987, Dryden, Ontario. pp. 56-75. Ontario Ministry of Natural Resources, Toronto, ON.

Wang, B.S.P. 1988. SADCC national tree seed centres. SADCC Project No. 6.0.5. A technical consultancy report for Consortium Interfor Inc. Sponsored by FSTCU/CIDA. Canadian International Development Agency, Hull, QC.

Wang, B.S.P. 2007. Highlights of my experiences in tree seed research and development at Petawawa. In T.L. Beardmore and J.D. Simpson (eds.). Proceedings, Recent Advances in Seed Physiology and Technology, IUFRO Research Group 2.09.00, 18-21 July 2006, Fredericton, NB, Canada. pp. 1-15.

Wang, B.S.P. and F. Ackerman. 1983. A new germination box for tree seed testing. Environment Canada, Canadian Forestry Service Petawawa National Forestry Institute, Petawawa, ON. Information Report PI-X-27. 15 p.

Wang, B.S.P. and P. Berjak. 2000. Beneficial effects of moist chilling on the seeds of black spruce (Picea mariana [Mill.] B.S.P.). Annals of Botany 86: 29-36.

Wang, B., S. D'Eon and J. Dong. 2006. Introduction of Canadian tree species to the Northeast of China. The Forestry Chronicle 82: 219-225.

Wang, B.S.P. and J.A. Pitel (eds.). 1982. Proceedings of the International Symposium on Forest Tree Seed Storage, 23-27 September 1980. Environment Canada, Canadian Forest Service Petawawa National Forestry Institute. 243 p.

Wang, B.S.P. and J.A. Pitel. 1991. Germination of dormant tree and shrub seeds. In A.G. Gordon, P. Gosling and B.S.P. Wang (eds.). Tree and Shrub Seed Handbook. International Seed Testing Association, Zurich, Switzerland.

Wang, B.S.P. and J.D. Simpson. 2004. Factors affecting tree seed storage. In Proceedings of the IUFRO Tree Seed Symposium, Seed Physiology and Technology Research Group 2.09.00, 20-22 September 2004, Nanjing, China. pp. 3-15.

Winston, D.A. and B.D. Haddon. 1981. Effects of early cone collection and artificial ripening on white spruce and red pine germination. Canadian Journal of Forest Research 11: 817-826. 